\title{
Lipid Sorting and Multivesicular Endosome Biogenesis
}

\author{
Christin Bissig and Jean Gruenberg \\ Biochemistry Department, University of Geneva, 1211 Geneva 4, Switzerland \\ Correspondence: jean.gruenberg@unige.ch
}

Intracellular organelles, including endosomes, show differences not only in protein but also in lipid composition. It is becoming clear from the work of many laboratories that the mechanisms necessary to achieve such lipid segregation can operate at very different levels, including the membrane biophysical properties, the interactions with other lipids and proteins, and the turnover rates or distribution of metabolic enzymes. In turn, lipids can directly influence the organelle membrane properties by changing biophysical parameters and by recruiting partner effector proteins involved in protein sorting and membrane dynamics. In this review, we will discuss how lipids are sorted in endosomal membranes and how they impact on endosome functions.

It is now well established that membranes along the endocytic and secretory pathway show differences not only in protein but also in lipid composition. For example, lipid gradients exist along the biosynthetic pathway with increasing density of cholesterol and sphingolipids from the endoplasmic reticulum (ER) to the plasma membrane (Maxfield and van Meer 2010). Also, phosphoinositides show distributions restricted to relatively well-characterized membrane territories (Di Paolo and De Camilli 2006). Given the facts that lipids are small and contain little structural information when compared with proteins, that they can diffuse rapidly within membranes, and that membranes are connected by membrane flow during transport, it is not always obvious how different lipids are segregated from each other.
In this article, we will evoke different mechanisms that may contribute to the heterogeneous lipid composition of endocytic membranes, including physicochemical properties of the membrane, interactions with other proteins or lipids, and synthesis or degradation. In addition, it has also become apparent that peripheral membrane proteins often interact with membranes via diverse lipid-binding motifs, and thus that lipids directly contribute to the distribution of many peripheral membrane proteins. For example, phosphatidylinositol 3-phosphate $(\mathrm{PI}(3) \mathrm{P})$ is detected predominantly on early endosomes, where most characterized PI(3)P-binding proteins encoded by the human genome are found as well (Raiborg et al. 2013). We will also discuss how some lipids may regulate protein sorting and membrane transport within the endosomal system.

Editors: Sandra L. Schmid, Alexander Sorkin, and Marino Zerial

Additional Perspectives on Endocytosis available at www.cshperspectives.org

Copyright (C) 2013 Cold Spring Harbor Laboratory Press; all rights reserved; doi: 10.1101/cshperspect.a016816

Cite this article as Cold Spring Harb Perspect Biol 2013;5:a016816 


\section{ORGANIZATION OF THE ENDOSOMAL PATHWAY}

Animal cells take up solutes, nutrients, ligands, and components of the plasma membrane via multiple endocytic pathways, which all merge in common early endosomes (Mayor and Pagano 2007; Doherty and McMahon 2009; Donaldson et al. 2013; Johannes et al. 2013; Kirchhausen et al. 2013; Merrifield and Kaksonen 2013). There, cargo can be sorted to different cellular destinations, including the plasma membrane, the trans-Golgi network (TGN), or late endosomes. Early endosomes contain tubular and cisternal elements, as well as vacuolar regions, where intralumenal vesicles (ILVs) of well-defined size, with a diameter of $\sim 50$ and $\sim 30 \mathrm{~nm}$ in mammalian and yeast cells, respectively (Mari et al. 2008; Pons et al. 2008; Wemmer et al. 2011), are formed by budding of the limiting membrane away from the cytosol toward the endosome lumen (Fig. 1) (Gruenberg 2001; Huotari and Helenius 2011). This process is interesting from a mechanistic and topological point of view, because it occurs in a direction opposite to classical membrane budding leading to vesicle or tubule formation in both the secretory and endocytic pathways (Hurley et al. 2010; Henne et al. 2013). Eventually, these multivesicular regions mature or detach from early endosomes and become free multivesicular endosomes, often referred to as multivesicular bodies or endosomal carrier vesicles (MVBs/ECVs), which deliver their ILV cargo to late endosomes and lysosomes for degradation. Much like early endosomes, late endosomes are highly pleiomorphic in mammalian cells with tubulo-cisternal as well as complex multivesicular or multilamellar regions. Also, endosomes may well contain different types of ILVs, since not all ILV proteins and lipids are destined for lysosomes, as discussed below.

The endocytic pathway can be divided into two functional territories: the reutilization/recycling and the degradation territories that are connected by membrane transport (Gruenberg 2001; Huotari and Helenius 2011). The first territory defines the trafficking pathway between the plasma membrane and early endosomal elements and amounts to the most prominent intracellular trafficking routes in mammalian cells, which are primarily used by constitutively cycling, housekeeping receptors. This territory is kept well segregated from late endocytic compartments, where degradation occurs, and trans-territory traffic is ensured by ECV/MVBmediated long distance, microtubule-dependent transport (Fig. 1).

\section{PHOSPHOLIPID COMPOSITION OF ENDOSOMAL MEMBRANES}

Lipids have the potential to generate $9000-$ 100,000 different molecular species (Shevchenko and Simons 2010), and it has long been appreciated that lipid species are not distributed equally among cellular membranes. It is becoming apparent that this heterogeneity in lipid distribution may provide a general organizing principle for the distribution of membrane-associated proteins. In fact, it was recently proposed that the vacuolar apparatus be divided into two main membrane regions (Leventis and Grinstein 2010; Bigay and Antonny 2012). In the ER/cis-Golgi, loose packing of poorly charged monounsaturated lipids would favor interactions with cytosolic proteins that prefer lipid-packing defects, whereas in the trans-Golgi/plasma membrane/endocytic membranes, tight packing of saturated, negatively charged lipids would favor electrostatic interactions.

In addition to the general principles outlined above, some specialized lipids are also distributed in a nonstochastic manner along the endocytic pathway (Fig. 1). The plasma membrane contains relatively high amounts of cholesterol and glycosphingolipids, and some lipids are asymmetrically distributed between the two bilayer leaflets. Although glycosphingolipids are only localized to the outer leaflet, phosphatidylethanolamine (PE) and phosphatidylserine (PS) are only present in the inner leaflet of the plasma membrane (Devaux 1991; Emoto et al. 1996). It is generally believed that early endosomes share the same overall lipid composition as the plasma membrane, as they are both part of the same recycling territory. Like the plasma membrane, early endosomes are rich in cholesterol and PS (Gagescu et al. 2000; Mobius et al. 2003; 


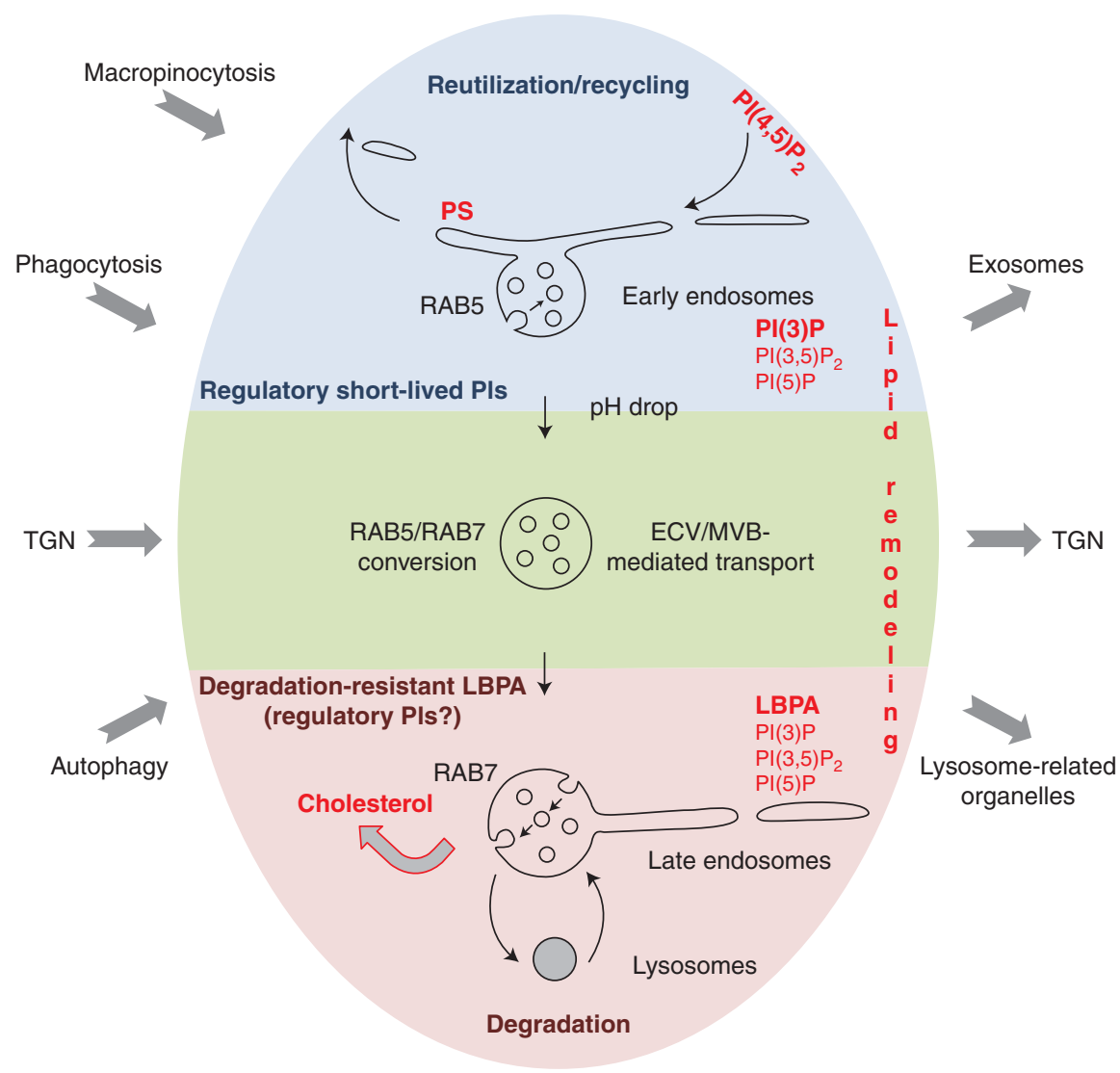

Figure 1. Organization of the endosomal pathway. In mammalian cells but perhaps not in yeast, the endocytic pathway can be divided into two functional territories, recycling/reutilization vs. degradation, which are linked by membrane transport. The plasma membrane and early endosomal elements belong to the recycling/reutilization territory through which large amounts of fluid or membrane are trafficked, $\sim 30 \%$ of the cell volume and the surface area of the plasma membrane per hour (Steinman et al. 1976; Besterman and Low 1983; Steinman et al. 1983), or perhaps more (Howes et al. 2010a). In early endosomes, cargo is sorted for recycling/reutilization or degradation. In the latter case, transport to late endosomes occurs via endosomal carrier vesicles/multivesicular bodies (ECVs/MVBs), where RAB5-to-RAB7 conversion may occur (Rink et al. 2005). This transport step ensures that recycling and degradation pathways remain well segregated. Importantly, the reutilization/recycling and degradation compartments not only fulfill distinct functions but also show different protein and lipid compositions. Regulatory short-lived phosphoinositides mediate dynamics of endosomal elements in the reutilization/recycling pathway. Less is known about the role of regulatory phosphoinositides at late stages of the degradation pathway, where degradation-resistant LBPA (lysobisphosphatidic acid) membranes may mediate intraendosomal dynamics and cholesterol export. Importantly, the endosomal pathway also serves as an input or output for other membrane trafficking pathways, as indicated.

Leventis and Grinstein 2010; Fairn et al. 2011). However, the two compartments differ in their phosphoinositide composition, with $\mathrm{PI}(4,5) \mathrm{P}_{2}$ and $\mathrm{PI}(3,4,5) \mathrm{P}_{3}$ found at the plasma membrane and PI(3)P on early endosomes (Gillooly et al. 2000). PI(3)P is not restricted to the endosomelimiting membrane, where it is synthesized, but it also seems to be relatively abundant in ILVs of multivesicular endosomes early in the pathway (Gillooly et al. 2000; Mobius et al. 2003). Cholesterol may show a somewhat similar distribution as PI(3)P (Gillooly et al. 2000; Mobius et al. 2003). Late endosomes are rich in lysobisphosphatidic acid (LBPA) (or bis(monoacyl- 
A

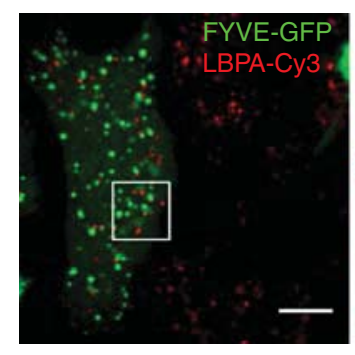

B

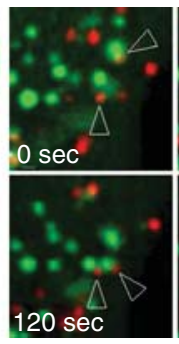

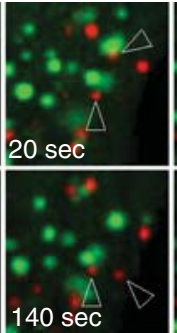
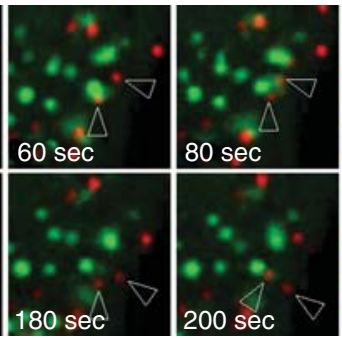

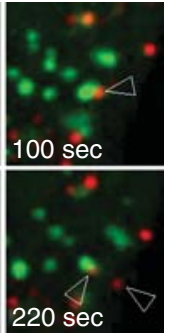

Figure 2. Dynamics of PI(3)P- and LBPA-containing endosomes in live cells. (A) HeLa cells were transfected with tandem FYVE-GFP and incubated overnight with mouse anti-LBPA and antimouse Cy3 antibodies. The concentration of anti-LBPA antibody $(2.5 \mu \mathrm{g} / \mathrm{mL}$ in medium $)$ and the levels of tandem FYVE-GFP expression were low to avoid possible interference with endosome dynamics. The cells were imaged in vivo and movies were taken at a frame rate of $0.6 \mathrm{sec}$ by time-lapse confocal microscopy. Panel $A$ shows in a still corresponding to the first frame that both cells contain endocytosed anti-LBPA antibodies but only the left cell expresses tandem FYVE-GFP. (B) Selected frames of the boxed magnified region. Arrowheads are showing movements of LBPApositive endosomes. Scale bar, $10 \mu \mathrm{m}$. (From Bissig et al. 2012; reprinted, with permission, from Elsevier.)

glycero)phosphate, BMP), which is not detected elsewhere in the cell, including in early endosomes, and is abundant in ILVs (Kobayashi et al. 1998). Endosomes may contain more than one population of ILVs with differences in fate and composition. Indeed, LBPA is present in ILVs of late, but not early, endosomes, whereas PI(3)P shows the opposite distribution (Fig. 2) (Gillooly et al. 2000; Kobayashi et al. 2002; Chevallier et al. 2008). Furthermore, LBPA is not enriched in exosomes, which may correspond to ILVs secreted after multivesicular endosome fusion with the plasma membrane (Wubbolts et al. 2003; Laulagnier et al. 2004). Despite continuous membrane flow, the phospholipid composition of each compartment is maintained, indicating that cells evolved mechanisms to sort lipids within compartments.

\section{LIPID CLUSTERING}

\section{Lipid Clustering by Physicochemical Properties In Vitro}

Although it is easy to perceive that proteins can be sorted via specific signals encoded in their peptide sequences, the notion of lipid sorting is not clearly defined, and is a matter of debate. If lipids contribute to their own sorting and thus to their restricted localization, one must evoke mechanisms based on their physical and chem- ical properties, which may in turn affect the bilayer curvature and electrostatics, as well as lipid packing (Callan-Jones et al. 2011; Bigay and Antonny 2012). In vitro, some lipid species tend to segregate from others probably because of their different physicochemical properties. In addition, when compared with flat membranes, highly curved membranes accommodate different lipid species in vitro provided that these are close to phase separation, to compensate for membrane compression and bending stiffness (Roux et al. 2005; Sorre et al. 2009; Tian and Baumgart 2009). Lipid-lipid interactions play an important role in in vitro lipid segregation processes. In line with this, the raft hypothesis predicts that cholesterol, sphingolipids, and proteins, upon demixing from the surrounding membrane components by phase separation, form dynamic nanoscale assemblies, referred to as lipid rafts, which may coalesce into larger platforms involved in signaling and trafficking (Lingwood and Simons 2010). In fact, it has been recently proposed that liquid phase separation may be of wider importance, as one of the underlying principles of cytoplasmic and nuclear compartments (Hyman and Simons 2012).

\section{Lipid Clustering In Vivo}

At the cell surface, both simian virus 40 and Shiga toxin can cluster their glycosphingolipid re- 
ceptors and thus impose a geometry on the lipids, which induces membrane tubulation and leads to lipid sorting into these invaginations (Romer et al. 2007; Ewers et al. 2010). Owing to its lipid and actin dependence, this pathway is reminiscent of the CLIC-GEEC pathway that mediates internalization of glycosylphosphatidylinositol (GPI)-anchored proteins (Howes et al.2010b). However, much less is known about protein-independent clustering of lipids.

One of the major limitations in studying lipid organization in membranes in vivo is that lipid nanostructures are very difficult to visualize, because of their small size and highly dynamic nature (Prior et al. 2003; Sharma et al. 2004). Highresolution mapping by electron microscopy now revealed that PS is not homogenously distributed within the plasma membrane, but is localized to nanoclusters, which are associated with cholesterol and sphingomyelin-rich caveolae (Fairn et al. 2011; Kay et al. 2012). Interestingly, cholesterol and sphingomyelin are also found together with PS in early and recycling endosomes (Gagescu et al. 2000; Mobius et al. 2003; Mondal et al. 2009). Thus, one may speculate that PS preferentially copartitions with cholesterolrich membranes in vivo, which are in turn targeted to the recycling pathway. If specialized lipids tend to assemble in nanodomains in vivo, these are unlikely to result strictly from the physicochemical properties of the lipids, but presumably arise from a combination of lipid-lipid, protein-protein, and lipid-protein interactions. Indeed, integral and peripheral proteins may influence-but also show preferences for-physical or chemical membrane properties, and thus may be preferentially sorted into curved versus flat or tightly versus loosely packed membranes (CallanJones et al. 2011; Bigay and Antonny 2012).

\section{RESTRICTED LIPID LOCALIZATION VIA SPATIALLY AND TEMPORALLY CONTROLLED SYNTHESIS AND TURNOVER: SHORT-LIVED PHOSPHOINOSITIDES}

Lipid restriction to distinct compartments might also be achieved by temporal and spatial regulation of lipid synthesis and turnover (Fig. 3A). Such a mechanism is well established for short-lived phosphoinositides that are rapidly turned over by kinases and phosphatases, but might also apply for other lipids (see below).

$\mathrm{PI}(3) \mathrm{P}$ is generated on early endosomes mostly by the action of the class III PI3-kinase, VPS34, which phosphorylates the D-3 position of the inositol ring of PI (Schu et al. 1993; Shin et al. 2005) and is turned over by 3-phosphatases, such as mammalian myotubularin (MTM)and myotubularin-related (MTMR) (Clague and Lorenzo 2005). Generation of PI(3)P on early endosomes is directly controlled by the small GTPase RAB5, a master regulator of early endosomal dynamics, because VPS34 is itself an RAB5 effector. In turn, several RAB5 effectors, such as EEA1 (early endosome antigen 1) and rabenosin-5, contain themselves a $\mathrm{PI}(3) \mathrm{P}$-binding FYVE (Fablp, YOTB, Vaclp, EEA1) domain that is required for endosomal targeting. Thus, RAB5 stimulates $\mathrm{PI}(3) \mathrm{P}$ synthesis in a positivefeedback loop (Zerial and McBride 2001). The 3-phosphatase MTM1 was shown to directly associate with VPS34 and is thus also localized to early endosomes (Cao et al. 2007). Although it remains unclear whether VPS34 and MTM1 are simultaneously active, their concomitant presence on early endosomes points toward a local and rapid mechanism of PI(3)P turnover.

Furthermore, PI(3)P can be metabolized to $\mathrm{PI}(3,5) \mathrm{P}_{2}$ by the $\mathrm{PI}(3) \mathrm{P}$ 5-kinases Fablp in yeast (Odorizzi et al. 1998) and PIKfyve in mammalian cells (Sbrissa et al. 2002b). The localization of $\mathrm{PI}(3,5) \mathrm{P}_{2}$ within the endocytic pathway is still unclear, because direct intracellular visualization of the lipid has been extremely difficult until now, as all $\mathrm{PI}(3,5) \mathrm{P}_{2}$-binding PROPPINs ( $\beta$ propellers that bind phosphoinositides) also interact with PI(3)P (Dove et al. 2004; Jeffries et al. 2004; Stromhaug et al. 2004; Baskaran et al. 2012). Furthermore, $\mathrm{PI}(3,5) \mathrm{P}_{2}$ localization is additionally complicated by the fact that it is a very minor lipid in nonstimulated cells, although its synthesis can be induced by osmotic stress (Cooke et al. 1998). The kinase PIKfyve/Fablp, which synthesizes $\mathrm{PI}(3,5) \mathrm{P}_{2}$, contains a $\mathrm{PI}(3) \mathrm{P}$ binding FYVE domain that presumably recruits the protein to early endosomes (Cabezas et al. 2006; Ikonomov et al. 2006; Rutherford et al. 2006), in which the substrate $\mathrm{PI}(3) \mathrm{P}$ is also 
C. Bissig and J. Gruenberg

A

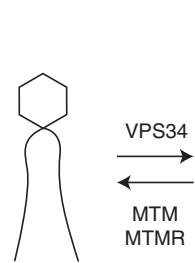

$\mathrm{PI}$

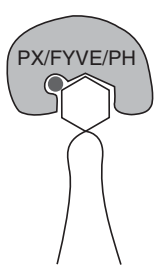

$\mathrm{PI}(3) \mathrm{P}$

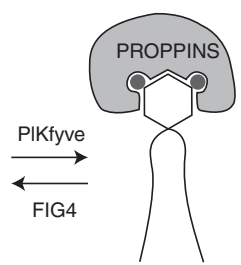

$\mathrm{PI}(3,5) \mathrm{P}_{2}$

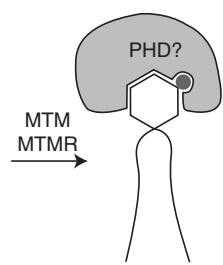

$\mathrm{PI}(5) \mathrm{P}$

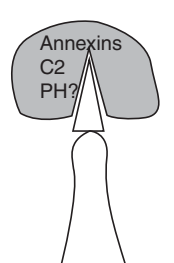

PS

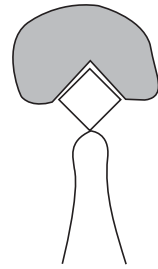

LBPA

B

\begin{tabular}{|c|c|c|c|c|c|c|c|c|c|c|c|}
\hline Lipid & \multicolumn{6}{|c|}{$\mathrm{PI}(3) \mathrm{P}$} & $\mathrm{Pl}(3,5) \mathrm{P}_{2}$ & $\mathrm{PI}(5) \mathrm{P}$ & PS & Cholesterol & LBPA \\
\hline $\begin{array}{c}\text { Lipid } \\
\text { Iocalization }\end{array}$ & \multicolumn{6}{|c|}{ EE/MVBa } & EE-to-LEh & $?$ & $\begin{array}{c}\mathrm{PM} / \mathrm{EE} / \\
\mathrm{RE}^{\mathrm{k}}\end{array}$ & $\begin{array}{l}\text { Endocytic } \\
\text { pathwaym }\end{array}$ & $\mathrm{LE}^{\circ}$ \\
\hline Protein & $\begin{array}{c}\text { RAB } \\
\text { effectors }{ }^{b}\end{array}$ & $\begin{array}{l}\text { SNX1 } \\
\text { SNX2c }\end{array}$ & $\mathrm{SNX} 3^{\mathrm{d}}$ & $\mathrm{HRS}^{\mathrm{e}}$ & ALFYf & PIKfyve $^{g}$ & $\begin{array}{l}\text { Atg18 } \\
\text { Atg2 } 21^{i}\end{array}$ & ? & EVT2! & $\begin{array}{l}\text { NPC1 } \\
\text { NPC2 }^{n}\end{array}$ & $\begin{array}{c}\text { ALIX } \\
\text { HSP70 }\end{array}$ \\
\hline $\begin{array}{l}\text { Lipid- } \\
\text { binding } \\
\text { domain }\end{array}$ & $\begin{array}{l}\text { FYVE } \\
\text { PX }\end{array}$ & $\begin{array}{l}\text { PX } \\
\text { BAR }\end{array}$ & PX & FYVE & FYVE & FYVE & PROPPIN & ? & $\mathrm{PH}$ & & \\
\hline $\begin{array}{l}\text { Protein } \\
\text { function }\end{array}$ & $\begin{array}{l}\text { Docking/ } \\
\text { fusion } \\
\text { Motility }\end{array}$ & $\begin{array}{l}\text { Retrograde } \\
\text { transport }\end{array}$ & $\begin{array}{c}\text { ILV } \\
\text { formation } \\
\text { Retrograde } \\
\text { transport } \\
\text { Iron } \\
\text { regulation }\end{array}$ & $\begin{array}{l}\text { ILV } \\
\text { formation } \\
\text { Receptor } \\
\text { sorting }\end{array}$ & Autophagy & $\begin{array}{l}\mathrm{PI}(3,5) \mathrm{P}_{2} \\
\text { synthesis }\end{array}$ & Autophagy & $\begin{array}{c}\text { Receptor } \\
\text { degradation } \\
\text { /sorting }\end{array}$ & $\begin{array}{l}\text { Retrograde } \\
\text { transport }\end{array}$ & $\begin{array}{l}\text { Endosome } \\
\text { dynamics }\end{array}$ & $\begin{array}{c}\text { ILV } \\
\text { formation } \\
\text { and fission } \\
\text { Lysosome } \\
\text { stabilization }\end{array}$ \\
\hline
\end{tabular}

Figure 3. Phospholipid-binding domains and proteins involved in endosomal dynamics. (A) A schematic illustration of key endosomal lipids and their phospholipid-binding domains is shown, including kinases and phosphatases involved in endosomal phosphoinositide generation and turnover. However, other pathways may also exist for the generation of PI(5)P. Enzymes involved in the metabolism of phosphatidylserine (PS), which is synthesized in the ER like most phospholipids, are not shown. The enzymes involved in LBPA synthesis and degradation are not known. (B) Key endosomal lipids and their localization (light gray) are shown with the corresponding phospholipid-binding proteins and their endosomal functions (dark gray). ${ }^{\mathrm{a}}$ Mobius et al. 2003; bimonsen et al. 1998; McBride et al. 1999; Pankiv et al. 2010; ${ }^{\mathrm{c} C}$ Carlton et al. 2004; Bonifacino and Hurley 2008; ${ }^{\mathrm{d}}$ Pons et al. 2008; Harterink et al. 2011; Chen et al. 2013; ${ }^{\mathrm{C}}$ Lloyd et al. 2002; Bache et al. 2003; Pons et al. 2008; ${ }^{f}$ Simonsen et al. 2004; Filimonenko et al. 2010; ${ }^{\mathrm{g}}$ Sbrissa et al. 2002a; ${ }^{\mathrm{h}}$ Cabezas et al. 2006; Ikonomov et al. 2006; Rutherford et al. 2006; ${ }^{i}$ see Tooze and Elazar 2013; and references in Mayinger 2012; ${ }^{j}$ Ramel et al. 2011; Zolov et al. 2012; Oppelt et al. 2013; ${ }^{\mathrm{k}}$ Gagescu et al. 2000; Leventis and Grinstein 2010; Fairn et al. 2011; ${ }^{\mathrm{I}}$ Uchida et al. 2011; ${ }^{\mathrm{m}}$ Mobius et al. 2003; Ikonen 2008; Maxfield and van Meer 2010; ${ }^{\mathrm{n}}$ Vanier and Millat 2003; Ohgami et al. 2004; Xu et al. 2007; Kwon et al. 2009; ${ }^{\circ}$ Kobayashi et al. 1999, 2002; ${ }^{\mathrm{P}}$ Matsuo et al. 2004; Kirkegaard et al. 2010; Bissig et al. 2013.

found. It is thus likely that $\mathrm{PI}(3,5) \mathrm{P}_{2}$ synthesis begins in early endosomes, and may continue at later stages of the pathway. $\mathrm{PI}(3,5) \mathrm{P}_{2}$ turnover is mediated by the 3-phosphatases of the MTM/ MTMR family and the 5-phosphatase factor-induced gene 4 protein (Fig. 4), which is found in a complex with PIKfyve (Duex et al. 2006), showing that synthesis and turnover are tightly coupled. The activity of MTM/MTMR phosphatase may also generate PI(5)P (Zolov et al. 2012;
Oppelt et al. 2013), a minor lipid that can be increased by various stimuli and might also play a role in lysosomal targeting (Fig. 3) (Ramel et al. 2011).

\section{LIPIDS AS ORGANIZING PRINCIPLES OF PERIPHERAL MEMBRANE PROTEINS}

Many proteins involved in the regulation of endosomal dynamics contain phospholipid-bind- 
ing domains (Fig. 3B). These phospholipidbinding domains are typically present in proteins that interact transiently with membranes and thus show relatively low binding affinity toward their target lipids to ensure rapid association-dissociation kinetics. These domains interact with the membrane either via specific recognition of rare lipids, such as phosphoinositides, or via recognition of physicochemical properties of the bilayer, such as curvature, lipid packing, or electrostatics (Bigay and Antonny 2012). Additionally, phospholipid-binding domains are often accompanied by other lipid- or protein-binding motifs, thus allowing for coincidence detection of multiple factors to stabilize proper membrane localization (Moravcevic et al. 2012). Thus, lipids act as organizing principles for membrane-associated proteins and their functions.

\section{PI(3)P-Controlled Membrane Dynamics,} Sorting, and Transport in Endosomes

$\mathrm{PI}(3) \mathrm{P}$ regulates most, if not all, key early endosome functions, including membrane dynamics, lysosome targeting, and retrograde transport (Figs. 1 and 3B), by the recruitment of effector proteins that interact with $\mathrm{PI}(3) \mathrm{P}$ via specific lipid-binding domains, such as the FYVE domain and the PX (phox) domain (Lemmon 2008). The role of PI(3)P in early endosome membrane dynamics is highlighted by the fact that many effectors of the small GTPase RAB5 are themselves $\mathrm{PI}(3) \mathrm{P}$-binding proteins, including the FYVE domain-containing tethering factor EEA1, which interacts with SNARE proteins in membrane docking/fusion (Simonsen et al. 1998; McBride et al. 1999). The role of RAB proteins, including the RAB5-to-RAB7 conversion that accompanies ECV/MVB-mediated transport from early-to-late endosomes (Fig. 1 ) is discussed elsewhere in the collection (Pfeffer and Wandinger-Ness 2013). PI(3)P also plays a direct role in endosome mobility by recruiting the kinesin-3, KIF16B, which contains a PI(3)P-binding PX domain (Hoepfner et al. 2005). Similarly, the plus end-directed transport of autophagic vesicles, which fuse with late endocytic elements, is promoted by the PI(3)P ef- fector FYCO1 (FYVE and coiled-coil domaincontaining protein 1) (Pankiv et al. 2010), in line with the fact that $\mathrm{PI}(3) \mathrm{P}$ is required for autophagosome biogenesis via recruitment of $\mathrm{PI}(3) \mathrm{P} \mathrm{ef}-$ fectors (Simonsen et al. 2004; Filimonenko et al. 2010; Noda et al. 2010; Tooze et al 2013).

In addition, $\mathrm{PI}(3) \mathrm{P}$ also initiates the molecular sequence of events leading to the downregulation of ubiquitinated cargo proteins in lysosomes, including activated signaling receptors. Indeed, inhibition of $\mathrm{PI}(3) \mathrm{P}$ synthesis with wortmannin, a drug that inhibits PI3-kinases, impairs ILV formation (Fernandez-Borja et al. 1999), and traps signaling receptors in early endosomes, thus inhibiting their degradation (Petiot et al. 2003). The effects of wortmannin reflect the role of $\mathrm{PI}(3) \mathrm{P}$ in the recruitment of ESCRT complexes that mediate sorting of ubiquitinated cargo proteins into ILVs, and in particular, the recruitment of the ESCRT-0 subunit HRS, a PI(3)P-binding protein that contains a FYVE motif, and initiates the sorting sequence. Depletion of HRS in mammalian cells (Bache et al. 2003; Pons et al. 2008) or mutagenesis in flies (Lloyd et al. 2002), decreases ILV formation and impairs signaling receptor degradation. However, the time course and extent of epidermal growth factor (EGF) transcriptional response do not appear to be affected by depletion of HRS or other ESCRT subunits, suggesting that the EGF response is set in motion primarily by active receptors present at the cell surface or perhaps also in endosomal elements of the reutilization/recycling territory (Fig. 1) (Brankatschk et al. 2012; Sousa et al. 2012). In addition, we find that ILV formation, but not EGF receptor degradation, is inhibited by depletion of SNX3, another PI(3)P-binding protein containing a PX motif (Pons et al. 2008, 2012), indicating that lysosomal targeting can be uncoupled from ILV formation, in agreement with previous observations (Mayran et al. 2003; Morel et al. 2009). Moreover, SNX3 in complex with VPS26-VPS29-VPS35 may also regulate very selectively the endosome-to-TGN transport of Wntless (Harterink et al. 2011). Recent evidence indicates that SNX3 may also control iron assimilation and transferrin receptor recycling (Chen et al. 2013). The mechanism by which SNX3 
regulates membrane dynamics, Wntless transport, iron assimilation, and ILV formation, is still elusive. Remarkably, SNX3 does not contain any structural features other than the PX domain (Xu et al. 2001), and it remains to be investigated whether SNX3 directly induces membrane invaginations or whether it recruits other proteins, for example, ESCRT subunits.

\section{Regulatory Short-Lived Phosphoinositides in Transport to/from Endosomes}

$\mathrm{PI}(3) \mathrm{P}-$ binding proteins also regulate retromer-dependent endosome-to-TGN transport. Retrograde transport and the retromer complex are discussed in detail elsewhere in this collection (Burd and Cullen 2013). The classical retromer complex is built of two subcomplexes: the membrane-binding SNX-BAR heterodimer and the cargo selection VPS26-VPS29-VPS35 subcomplex (Bonifacino and Hurley 2008; Cullen and Korswagen 2012). The SNX-BAR subcomplex, which is formed by a SNX heterodimer (SNX1 or SNX2 with either SNX5, SNX6, or SNX32), mediates retromer recruitment to early endosomes via its PI(3)P-binding PX domain and its curvature-sensing BAR domain (Carlton et al. 2004). As mentioned, SNX3 in complex with VPS26-VPS29-VPS35 might also regulate Wntless retrograde transport (Harterink et al. 2011).

$\mathrm{PI}(3) \mathrm{P}$ is also a substrate for the generation of $\mathrm{PI}(3,5) \mathrm{P}_{2}$, which in turn can be metabolized to PI(5)P (Fig. 3A) (Zolov et al. 2012; Oppelt et al. 2013). It is very likely that $\operatorname{PI}(3,5) \mathrm{P}_{2}$ and $\mathrm{PI}(5) \mathrm{P}$, together with their effector proteins, also play active roles in endosomal dynamics. However, we still know relatively little about their exact functions. In yeast $\mathrm{PI}(3,5) \mathrm{P}_{2}$-binding PROPPIN proteins, such as Atg18 and Atg21, have been implicated in autophagosome maturation and vacuole homeostasis (Mayinger 2012; Tooze et al. 2013). Further roles of $\mathrm{PI}(3,5) \mathrm{P}_{2}$ in animal cells seem to be the activation of mucolipin transient receptor potential ion channel (Dong et al. 2010), regulation of autophagy in the nervous system (Ferguson et al. 2010), and cardiac contractility via activation of the ryanodine receptor (Touchberry et al.
2010). The role of PI(5)P is much less clear, but one can speculate that it is involved in lysosomal targeting of signaling receptors (Ramel et al. 2011). Altogether, these data indicate that phosphoinositides act as a fundamental organizing principle in the endocytic pathway (Fig. 1).

\section{RESTRICTED LIPID LOCALIZATION VIA SPATIALLY CONTROLLED SYNTHESIS AND TURNOVER: LONG-LIVED LBPA}

In late endosomes, LBPA makes up 15 mole $\%$ of total phospholipids. The main LBPA isoform is $2,2^{\prime}$-dioleoyl LBPA, which accounts for $>80 \%$ of total LBPA in baby hamster kidney cells (BHK) (Kobayashi et al. 1998, 2002) and seems to be the major biologically active isoform (Matsuo et al. 2004; Chevallier et al. 2008). 2,2'LBPA is thermodynamically unstable, as the fatty acid chains can migrate to form 3,3'-LBPA (Fig. 4) (Chevallier et al. 2000; Kobayashi et al. 2002). The position of LBPA fatty acyl chains is expected to have dramatic effects on the overall structure of the lipid and is thus likely to modulate its biological functions. Quantum mechanical simulations of molecular electronic energies of 2,2' - and 3,3'-LBPA indeed suggest that the two isomers show significantly different shapes (Goursot et al. 2010).

Phospholipids of the vacuolar apparatus are synthesized in the early biosynthetic pathway and then redistribute throughout organellar membranes primarily by membrane flow, with some being unevenly distributed along trafficking pathways, as mentioned. It is thus surprising that LBPA, with its characteristic phospholipidic backbone (Fig. 4), is only found in late endosomal membranes, and is not detected elsewhere. This strongly argues for its localized synthesis in the late endosomal compartment from a phospholipidic precursor. Indeed, it has been shown that two polyglycerophospholipids, phosphatidylglycerol (PG), a structural isomer of LBPA and cardiolipin, can be converted to LBPA in in vivo systems (Poorthuis and Hostetler 1975; Somerharju and Renkonen 1980; Amidon et al. 1995). However, it was also shown that only PG, but not cardiolipin, serves as a possible precursor for de novo LBPA biosynthesis in 


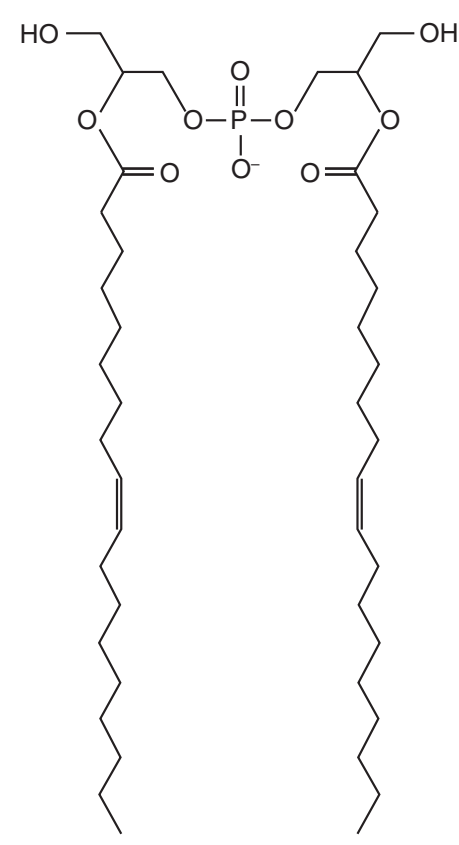

$2,2^{\prime}$-LBPA

Endosomal Lipids

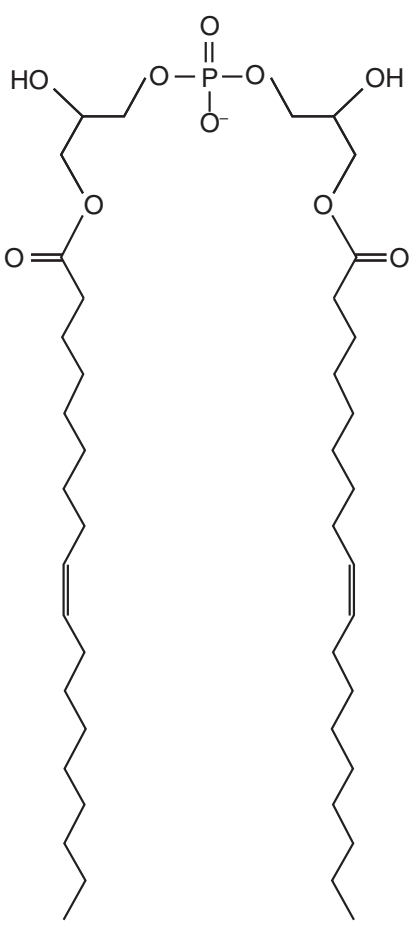

3,3'-LBPA

Figure 4. Chemical structures of the 2,2'- and 3,3'-dioleoyl LBPA isoforms. The major isoform present in late endosomes of BHK cells is $2,2^{\prime}$-dioleoyl LBPA. This isoform is thermodynamically unstable and the fatty acid chains can migrate to the $3,3^{\prime}$ positions of the glycerol backbone to form the $3,3^{\prime}$-LBPA isoform.

vivo (Hullin-Matsuda et al. 2007). Strikingly these studies also show that despite decreased de novo LBPA synthesis in cells deficient for PG synthesis, the total LBPA amount remains unchanged, indicating that some other biosynthetic pathway must exist. Moreover, PG, like cardiolipin, is primarily found in mitochondria suggesting that these lipids may be delivered to late endocytic compartments by autophagy ( $\mathrm{Ru}-$ binsztein et al. 2012), to serve as precursors in LBPA biosynthesis. Finally, LBPA is a poor substrate for lipases and phospholipases, which has led to the notion that it may be the stereoisomer of other naturally occurring phospholipids (Brotherus et al. 1974; Joutti 1979; Thornburg et al. 1991; Chevallier et al. 2000), as was recently shown (Tan et al. 2012). This notion is consistent with observations that LBPA facilitates the degradation of glycosphingolipids in vitro by enhancing the lipid-extraction capacity of saposins
(Kolter and Sandhoff 2010). LBPA may also facilitate HSP70 entry into lysosomes and lysosome stabilization (Kirkegaard et al. 2010).

The ESCRT-associated cytosolic protein ALIX is recruited to endosomes via interactions with LBPA (Matsuo et al. 2004; Bissig et al. 2013) indicating that the lipid can be found on the cytoplasmic leaflet of the endosome-limiting membrane-and yet it is presumably synthesized in the endosome lumen from a precursor lipid, where it can be accessed by endocytosed antibodies (Kobayashi et al. 1998, 1999). Hence, if LBPA is present in both leaflets of the late endosomal-limiting membrane and if it is synthesized in late endosomes, it needs to be translocated to the cytoplasmic leaflet. Because of its low pKa, LBPA is expected to remain negatively charged at the late endosomal $\mathrm{pH}$ of 5.5 (Wilkening et al. 2000). However, LBPA self-assembly may cause partial protonation of proximal LBPA 
phosphate groups. In this case, the protonated LBPA molecule could undergo spontaneous transbilayer redistribution. Alternatively, LBPA may be translocated across the bilayer by some as-yet-unidentified flippase. Finally, late endosomes, in contrast to ECVs/MVBs, contain complex and often poorly defined intralumenal protein-lipid systems - see, for example, Kobayashi et al. (2002) and Matsuo et al. (2004) which may in part reflect nonbilayer structures in dynamic equilibrium with lumenal membranes, a situation that may favor LBPA redistribution across bilayers.

\section{LIPID-MEDIATED ENDOSOMAL DYNAMICS}

It is well established that endosomal membranes are endowed with the capacity to become deformed in two opposite directions: toward the cytosol much like at other membrane transport steps during tubule or vacuole biogenesis, and toward the endosome lumen during ILV biogenesis. These two membrane deformation processes must be tightly coordinated to maintain the homeostatic membrane balance. The molecular mechanisms are not well understood, although much progress has been made in the characterization of each process individually. $\mathrm{Na}$ scent tubules of recycling endosomes selectively incorporate the Man6P receptor sorted via the retromer complex, which is recruited onto membranes by the dual capacity of sorting nexins to interact with both $\mathrm{PI}(3) \mathrm{P}$ via the PX domain and curved membranes via the curvature-sensing BAR domain (Bonifacino and Hurley 2008). Retromer recruitment and tubule biogenesis may be coordinated by RAB5-to-RAB7 conversion (Rojas et al. 2008; Seaman et al. 2009; Balderhaar et al. 2010; Liu et al. 2012; van Weering et al. 2012), and recent lines of evidence indicate that this process may also involve the actin cytoskeleton (Seaman 2012). During ILV formation, the sorting of ubiquitinated cargo proteins is achieved by ESCRT complexes, which may also be involved in the membrane deformation and scission processes (Wollert and Hurley 2010; Henne et al. 2012). However, in addition to proteins, it has long been thought that lipids also play an important role in membrane deforma- tion; in particular, during the formation of intralumenal membranes (Mukherjee et al. 1999; Babst 2011).

It has been shown that LBPA has the intrinsic capacity to deform membranes in vitro (Matsuo et al. 2004), a situation that probably reflects ILV formation within late endosomes in vivo. However, only the $2,2^{\prime}$-LBPA isoform, but not $3,3^{\prime}$-LBPA, triggers vesicle formation within acidic liposomes, in a process that is controlled by its partner, the ESCRT-associated protein ALIX (Matsuo et al. 2004; Frederick et al. 2010). ALIX specificity toward LBPA is conferred by a flexible loop in the Brol domain that undergoes a conformational change upon membrane association and requires a calcium atom bound near the lipid interaction site (Bissig et al. 2013). ALIX also regulates the formation of ILVs within acidic late endosomes in vitro (Falguieres et al. 2008). The regulatory function of ALIX and LBPA in ILV formation is further supported by observations that ALIX knockdown reduces LBPA and the number of ILVs (Matsuo et al. 2004; Chevallier et al. 2008), and that both can be restored in this knockdown background by the addition of 2,2'-LBPA (Chevallier et al. 2008). Thus, LBPA molecules that appear on the endosome-limiting membrane may be reincorporated into nascent ILVs, a mechanism that may explain the restricted distribution of LBPA to multivesicular elements of late endosomes. Typically, LBPA is not detected in the dynamic, cisternal, or tubular regions of late endosomes, which contain the PX-containing protein SNX16 (Brankatschk et al. 2011). This may suggest that PI(3)P is also present in late endosomes or that SNX16 is stabilized on late endosomal membranes by other protein-lipid or protein-protein interactions. Importantly, interfering with LBPA (Luyet et al. 2008) or ALIX (Schmidt et al. 2004; Cabezas et al. 2005; Bowers et al. 2006; Doyotte et al. 2008; Luyet et al. 2008) does not affect the trafficking of EGF receptor to lysosomes, nor EGF receptor down-regulation, despite the fact that ALIX interacts with the two ESCRT subunits TSG101 and CHMP4 in mammalian cells. ALIX, however, may be involved in the ubiquitin-independent, ESCRT-III-dependent sorting of the GPCR PAR1 (Dores et al. 2012). 


\section{ENDOSOMAL TRAFFICKING OF CHOLESTEROL}

Cholesterol is abundant in all post-Golgi membranes, together with sphingolipids, and their levels increase along the biosynthetic pathway, which presumably impacts on the length of protein transmembrane domains by changing membrane thickness (Sharpe et al. 2010). In the endocytic pathway, cholesterol is thought to localize primarily to recycling endosomes and multivesicular endosomes, where it is also abundant in ILVs (Mobius et al. 2003). In contrast, lysosomes are known to contain little cholesterol. Endosomes acquire cholesterol as a membrane component via trafficking routes, or as cholesteryl esters by receptor-mediated endocytosis of low-density lipoprotein (LDL) - the latter pathway constitutes the major cellular cholesterol source in most cell types (Brown and Goldstein 1976). In late endosomes, acid lipase hydrolyses cholesteryl esters and the resulting free cholesterol partitions into neighboring membranes. However, the mechanism of cholesterol export from endosomes to other cellular destinations is still a matter of debate (Ikonen 2008; Maxfield and van Meer 2010).

LDL-derived cholesterol and glycosphingolipids accumulate in late endocytic compartments of patients with Niemann-Pick type C (NPC) disease (Vanier and Millat 2003). This disease leads to progressive neurodegeneration and infantile death and is caused by mutations in NPC-1 or NPC-2 proteins (Miller and Bose 2011). NPC-1 is a 13-transmembrane-spanning glycoprotein found in the limiting membrane of late endosomes, whereas NPC- 2 is a soluble protein of the late endosomal lumen. Biochemical and structural studies have shown that both proteins bind sterols (Ohgami et al. 2004; Xu et al. 2007; Kwon et al. 2009) and it has been proposed that the lumenal protein NPC-2 extracts cholesterol from ILVs and transports it to NPC-1, which mediates insertion into the limiting membrane (Infante et al. 2008). It has also been proposed that sphingosine acts as an initiating factor in the NPC pathogenesis by altering calcium homeostasis (Lloyd-Evans et al. 2008). Several lines of evidence indicate that the late endosomal lipid
LBPA and its partner protein ALIX play a role in cholesterol export (Kobayashi et al. 1999; Le Blanc et al. 2005; Chevallier et al. 2008). After de-esterification, free cholesterol is likely to partition preferentially into ILV membranes as they are highly abundant, where it might readily flipflop across the bilayer (Parisio et al.2012). ALIXand LBPA-dependent back fusion of ILVs with the limiting membrane may then control cholesterol export from endosomes.

\section{LIPID-DEPENDENT EXPORT FROM ENDOSOMES}

The notion that ILV back fusion may contribute to ensure cholesterol export from endosomes is further supported by observations that proteins and lipids present in late endosome intralumenal membranes are presumably not all destined for degradation in lysosomes, including LBPA itself and tetraspanins (Escola et al. 1998). Also molecules in transit through this compartment, including the Man6P receptor and the tetraspanin CD63 in endothelial cells, can escape delivery to lysosomes (Kobayashi et al. 1998, 2000). In addition, some ILVs with their protein and lipid cargo may be released as exosomes upon direct fusion of multivesicular endosomes with the plasma membranes, at least in some specialized cell types (Raposo and Stoorvogel 2013). This pathway is reminiscent of the secretory functions of lysosome-related organelles ( $\mathrm{Ra}$ poso et al. 2007), but it cannot be excluded that some multivesicular endosome population transiently acquires the capacity to fuse with the plasma membrane (Murk et al. 2002; Johnstone 2006). During melanosome formation, cargo sorting was recently shown to depend on CD63 but not ESCRTs (van Niel et al. 2011), whereas the biogenesis of exosomes may (Gibbings et al. 2009; Baietti et al. 2012) or may not (Trajkovic et al. 2008) depend on ALIX and ESCRTs. Moreover, vesicular stomatitis virus (VSV) (Le Blanc et al. 2005; Luyet et al. 2008; Bissig et al. 2013), Lassa virus, and lymphocytic choriomeningitis virus (Pasqual et al. 2011) hijack the endocytic pathway to gain entry into their host cells in a process that depends on LBPA, ALIX, and ESCRTs, as does the anthrax toxin lethal factor 
(Abrami et al. 2004). Both VSV nucleocapsid and anthrax toxin lethal factor may first be delivered into ILV lumen early in the pathway and then released into the cytoplasm by ILV back fusion with the endosome-limiting membrane (Abrami et al. 2004; Le Blanc et al. 2005; Luyet et al. 2008), a process presumably similar to that followed by cholesterol during export from endosomes.

Given the possible role of LBPA in ILV formation and back fusion, we speculate that LBPA forms microdomains or hot spots on the endosomal-limiting membrane, and thereby controls ILV dynamics via kiss-and-run fusion and fission cycles. Hence, it is attractive to conclude that ILVs function as sorting devices in the endosomal system.

\section{CONCLUDING REMARKS AND FUTURE CHALLENGES}

The significance of the vast diversity of lipid species is poorly understood (Shevchenko and Simons 2010). This diversity primarily is owing to the enormous repertoire of possible acyl chain positions, saturation, and length, as well as linkages, including ether and amide in addition to the common ester bond (Wenk 2005). In particular, for LBPA, differences in amounts and acyl chain composition, including length and saturation state, are observed in different cell types (e.g., Luquain et al. 2000; Kobayashi et al. 2002), and under pathological conditions (Vanier and Millat 2003; Meikle et al. 2008), suggesting that LBPA functions can be tuned not only by its abundance but also by changes in its composition. A future challenge will be to determine how cellular functions are regulated by the molecular structure of individual lipids as well as by the membrane lipid composition.

Although proteins can be manipulated by mutagenesis, including even at endogenous levels in genome-edited cells (Doyon et al. 2011), similar experiments are difficult or impossible when dealing with lipids. Changing the molecular structure of a lipid, in contrast to proteins, may affect the lipid architecture and its physicochemical properties so profoundly that it is no longer the same molecular species and thus shows different functional properties. And interfering with metabolic enzymes often results in compensatory changes in overall lipid homeostasis (Guan et al. 2009) or leads to the accumulation of a lipid intermediate with different properties, rendering such approaches difficult to interpret. A powerful alternative for interfering with the functions of lipids, and, in particular, of phosphoinositides, is the expression of lipid-specific reporter proteins (Lemmon 2008; Mayinger 2012). Yet, the selective manipulation of individual lipids in vivo remains a major challenge. In specific cases, the exogenous addition of lipids has proven to be useful. For example, the addition of aminophospholipid increases endocytosis in living cells (Farge et al. 1999) and adding the biologically active isoform, but not other isoforms, of LBPA reduces cholesterol overload in NPC cells (Chevallier et al. 2008). Finally, a promising approach has been elaborated by Carsten Schultz and colleagues that developed very elegant strategies to introduce membrane-permeant versions of phosphoinositides into cells so that the lipid is released upon cleavage by cytosolic esterases (Laketa et al. 2009; Mentel et al. 2011). Such strategies, together with the development of novel chemical biology tools, offer promising new ways to study the function of membrane lipids (Riezman and Johnsson 2011; Wymann and Schultz 2012).

\section{ACKNOWLEDGMENTS}

We are grateful to Gisou van der Goot and Aurélien Roux for critical reading of the manuscript and helpful comments. Support is from the PRISM EU Sixth Framework Program, the Swiss National Science Foundation, the Swiss Sinergia program, the Polish-Swiss Research Programme (PSPB-094/2010), the NCCR in Chemical Biology, and LipidX from the Swiss SystemsX.ch initiative, evaluated by the Swiss National Science Foundation (J.G.).

\section{REFERENCES}

${ }^{*}$ Reference is also in this collection.

Abrami L, Lindsay M, Parton RG, Leppla SH, van der Goot FG. 2004. Membrane insertion of anthrax protective an- 
tigen and cytoplasmic delivery of lethal factor occur at different stages of the endocytic pathway. J Cell Biol 166: 645-651.

Amidon B, Schmitt JD, Thuren T, King L, Waite M. 1995. Biosynthetic conversion of phosphatidylglycerol to $s n$ $1: s n-1^{\prime}$ bis(monoacylglycerol) phosphate in a macrophage-like cell line. Biochemistry 34: 5554-5560.

Babst M. 2011. MVB vesicle formation: ESCRT-dependent, ESCRT-independent and everything in between. Curr Opin Cell Biol 23: 452-457.

Bache KG, Brech A, Mehlum A, Stenmark H. 2003. Hrs regulates multivesicular body formation via ESCRT recruitment to endosomes. J Cell Biol 162: 435-442.

Baietti MF, Zhang Z, Mortier E, Melchior A, Degeest G, Geeraerts A, Ivarsson Y, Depoortere F, Coomans C, Vermeiren E, et al. 2012. Syndecan-syntenin-ALIX regulates the biogenesis of exosomes. Nat Cell Biol 14: 677685.

Balderhaar HJ, Arlt H, Ostrowicz C, Brocker C, Sundermann F, Brandt R, Babst M, Ungermann C. 2010. The Rab GTPase Ypt7 is linked to retromer-mediated receptor recycling and fusion at the yeast late endosome. J Cell Sci 123: 4085-4094.

Baskaran S, Ragusa MJ, Boura E, Hurley JH. 2012. Twosite recognition of phosphatidylinositol 3-phosphate by PROPPINs in autophagy. Mol Cell 47: 339-348.

Besterman JM, Low RB. 1983. Endocytosis: A review of mechanisms and plasma membrane dynamics. Biochem J 210: $1-13$.

Bigay J, Antonny B. 2012. Curvature, lipid packing, and electrostatics of membrane organelles: Defining cellular territories in determining specificity. Dev Cell 23: 886895.

Bissig C, Johnson S, Gruenberg J. 2012. Studying lipids involved in the endosomal pathway. Methods Cell Biol 108: 19-46.

Bissig C, Lenoir M, Velluz MC, Kufareva I, Abagyan R, Overduin M, Gruenberg J. 2013. Viral infection controlled by a calcium-dependent lipid-binding module in ALIX. Dev Cell 25: 364-373

Bonifacino JS, Hurley JH. 2008. Retromer. Curr Opin Cell Biol 20: 427-436.

Bowers K, Piper SC, Edeling MA, Gray SR, Owen DJ, Lehner PJ, Luzio JP. 2006. Degradation of endocytosed epidermal growth factor and virally ubiquitinated major histocompatibility complex class I is independent of mammalian ESCRTII. J Biol Chem 281: 5094-5105.

Brankatschk B, Pons V, Parton RG, Gruenberg J. 2011. Role of SNX16 in the dynamics of tubulo-cisternal membrane domains of late endosomes. PloS ONE 6: e21771.

Brankatschk B, Wichert SP, Johnson SD, Schaad O, Rossner MJ, Gruenberg J. 2012. Regulation of the EGF transcriptional response by endocytic sorting. Sci Signal 5: ra21.

Brotherus J, Renkonen O, Fischer W, Herrmann J. 1974. Novel stereoconfiguration in lyso-bis-phosphatidic acid of cultured BHK-cells. Chem Phys Lipids 13: 178-182.

Brown MS, Goldstein JL. 1976. Receptor-mediated control of cholesterol metabolism. Science 191: 150-154.

Cabezas A, Bache KG, Brech A, Stenmark H. 2005. Alix regulates cortical actin and the spatial distribution of endosomes. J Cell Sci 118: 2625-2635.
Cabezas A, Pattni K, Stenmark H. 2006. Cloning and subcellular localization of a human phosphatidylinositol 3phosphate 5-kinase, PIKfyve/Fab1. Gene 371: 34-41.

Callan-Jones A, Sorre B, Bassereau P. 2011. Curvaturedriven lipid sorting in biomembranes. Cold Spring Harb Perspect Biol 3: a004648.

Cao C, Laporte J, Backer JM, Wandinger-Ness A, Stein MP. 2007. Myotubularin lipid phosphatase binds the hVPS15/hVPS34 lipid kinase complex on endosomes. Traffic 8: 1052-1067.

Carlton J, Bujny M, Peter BJ, Oorschot VM, Rutherford A, Mellor H, Klumperman J, McMahon HT, Cullen PJ. 2004. Sorting nexin-1 mediates tubular endosometo-TGN transport through coincidence sensing of highcurvature membranes and 3-phosphoinositides. Curr Biol 14: 1791-1800.

Chen C, Garcia-Santos D, Ishikawa Y, Seguin A, Li L, Fegan KH, Hildick-Smith GJ, Shah DI, Cooney JD, Chen W, et al. 2013. Snx3 regulates recycling of the transferrin receptor and iron assimilation. Cell Metab 17: 343-352.

Chevallier J, Sakai N, Robert F, Kobayashi T, Gruenberg J, Matile S. 2000. Rapid access to synthetic lysobisphosphatidic acids using $\mathrm{P}^{\mathrm{III}}$ chemistry. Organic Lett 2: 1859 1861.

Chevallier J, Chamoun Z, Jiang G, Prestwich G, Sakai N, Matile S, Parton RG, Gruenberg J. 2008. Lysobisphosphatidic acid controls endosomal cholesterol levels. J Biol Chem 283: 27871-27880.

Clague MJ, Lorenzo O. 2005. The myotubularin family of lipid phosphatases. Traffic 6: 1063-1069.

Cooke FT, Dove SK, McEwen RK, Painter G, Holmes AB, Hall MN, Michell RH, Parker PJ. 1998. The stress-activated phosphatidylinositol 3-phosphate 5-kinase Fablp is essential for vacuole function in S. cerevisiae. Curr Biol 8: 1219-1222.

Cullen PJ, Korswagen HC. 2012. Sorting nexins provide diversity for retromer-dependent trafficking events. Nat Cell Biol 14: 29-37.

Devaux PF. 1991. Static and dynamic lipid asymmetry in cell membranes. Biochemistry 30: 1163-1173.

Di Paolo G, De Camilli P. 2006. Phosphoinositides in cell regulation and membrane dynamics. Nature 443: 651657.

Doherty GJ, McMahon HT. 2009. Mechanisms of endocytosis. Ann Rev Biochem 78: 857-902.

* Donaldson J. 2013. Clathrin-independent pathways (Caveole, GEECs, rafts, arf6). Cold Spring Harb Perspect Biol doi: 10.1101/cshperspect.a016758.

Dong XP, Shen D, Wang X, Dawson T, Li X, Zhang Q, Cheng $\mathrm{X}$, Zhang Y, Weisman LS, Delling M, et al. 2010. PI(3,5) $\mathrm{P}_{2}$ controls membrane trafficking by direct activation of mucolipin $\mathrm{Ca}^{2+}$ release channels in the endolysosome. Nat Commun 1: 38.

Dores MR, Chen B, Lin H, Soh UJ, Paing MM, Montagne WA, Meerloo T, Trejo J. 2012. ALIX binds a YPX $_{3}$ L motif of the GPCR PAR 1 and mediates ubiquitin-independent ESCRT-III/MVB sorting. J Cell Biol 197: 407-419.

Dove SK, Piper RC, McEwen RK, Yu JW, King MC, Hughes DC, Thuring J, Holmes AB, Cooke FT, Michell RH, et al. 2004. Svp1p defines a family of phosphatidylinositol 3,5bisphosphate effectors. EMBO J 23: 1922-1933. 
Doyon JB, Zeitler B, Cheng J, Cheng AT, Cherone JM, Santiago Y, Lee AH, Vo TD, Doyon Y, Miller JC, et al. 2011. Rapid and efficient clathrin-mediated endocytosis revealed in genome-edited mammalian cells. Nat Cell Biol 13: 331-337.

Doyotte A, Mironov A, McKenzie E, Woodman P. 2008. The Bro1-related protein HD-PTP/PTPN23 is required for endosomal cargo sorting and multivesicular body morphogenesis. Proc Natl Acad Sci 105: 6308-6313.

Duex JE, Tang F, Weisman LS. 2006. The Vac14p-Fig4p complex acts independently of Vac7p and couples PI3,5 $\mathrm{P}_{2}$ synthesis and turnover. J Cell Biol 172: 693-704.

Emoto K, Kobayashi T, Yamaji A, Aizawa H, Yahara I, Inoue K, Umeda M. 1996. Redistribution of phosphatidylethanolamine at the cleavage furrow of dividing cells during cytokinesis. Proc Natl Acad Sci 93: 1286712872.

Escola JM, Kleijmeer MJ, Stoorvogel W, Griffith JM, Yoshie O, Geuze HJ. 1998. Selective enrichment of tetraspan proteins on the internal vesicles of multivesicular endosomes and on exosomes secreted by human B-lymphocytes. J Biol Chem 273: 20121-20127.

Ewers H, Romer W, Smith AE, Bacia K, Dmitrieff S, Chai W, Mancini R, Kartenbeck J, Chambon V, Berland L, et al. 2010. GM1 structure determines SV40-induced membrane invagination and infection. Nat Cell Biol 12: $11-18$.

Fairn GD, Schieber NL, Ariotti N, Murphy S, Kuerschner L, Webb RI, Grinstein S, Parton RG. 2011. High-resolution mapping reveals topologically distinct cellular pools of phosphatidylserine. J Cell Biol 194: 257-275.

Falguieres T, Luyet PP, Bissig C, Scott CC, Velluz MC, Gruenberg J. 2008. In vitro budding of intralumenal vesicles into late endosomes is regulated by Alix and Tsg101. Mol Biol Cell 19: 4942-4955.

Farge E, Ojcius DM, Subtil A, Dautry-Varsat A. 1999. Enhancement of endocytosis due to aminophospholipid transport across the plasma membrane of living cells. Am J Physiol 276: C725-C733.

Ferguson CJ, Lenk GM, Meisler MH. 2010. PtdIns(3,5) $\mathrm{P}_{2}$ and autophagy in mouse models of neurodegeneration. Autophagy 6: 170-171.

Fernandez-Borja M, Wubbolts R, Calafat J, Janssen H, Divecha N, Dusseljee S, Neefjes J. 1999. Multivesicular body morphogenesis requires phosphatidyl-inositol 3-kinase activity. Curr Biol 9: 55-58.

Filimonenko M, Isakson P, Finley KD, Anderson M, Jeong H, Melia TJ, Bartlett BJ, Myers KM, Birkeland HC, Lamark T, et al. 2010. The selective macroautophagic degradation of aggregated proteins requires the PI3P-binding protein Alfy. Mol Cell 38: 265-279.

Frederick TE, Goff PC, Mair CE, Farver RS, Long JR, Fanucci GE. 2010. Effects of the endosomal lipid bis(monoacylglycero)phosphate on the thermotropic properties of DPPC: A 2H NMR and spin label EPR study. Chem Phys Lipids 163: 703-711.

Gagescu R, Demaurex N, Parton RG, Hunziker W, Huber LA, Gruenberg J. 2000. The recycling endosome of Madin-Darby canine kidney cells is a mildly acidic compartment rich in raft components. Mol Biol Cell 11: 2775-2791.
Gibbings DJ, Ciaudo C, Erhardt M, Voinnet O. 2009. Multivesicular bodies associate with components of miRNA effector complexes and modulate miRNA activity. Nat Cell Biol 11: 1143-1149.

Gillooly DJ, Morrow IC, Lindsay M, Gould R, Bryant NJ, Gaullier JM, Parton RG, Stenmark H. 2000. Localization of phosphatidylinositol 3-phosphate in yeast and mammalian cells. EMBO J 19: 4577-4588.

Goursot A, Mineva T, Bissig C, Gruenberg J, Salahub DR. 2010. Structure, dynamics, and energetics of lysobisphosphatidic acid (LBPA) isomers. JPhys Chem B 114: 15712 15720.

Gruenberg J. 2001. The endocytic pathway: A mosaic of domains. Nat Rev Mol Cell Biol 2: 721-730.

Guan XL, Souza CM, Pichler H, Dewhurst G, Schaad O, Kajiwara $\mathrm{K}$, Wakabayashi $\mathrm{H}$, Ivanova $\mathrm{T}$, Castillon GA, Piccolis M, et al. 2009. Functional interactions between sphingolipids and sterols in biological membranes regulating cell physiology. Mol Biol Cell 20: 2083-2095.

Harterink M, Port F, Lorenowicz MJ, McGough IJ, Silhankova M, Betist MC, van Weering JR, van Heesbeen RG, Middelkoop TC, Basler K, et al. 2011. A SNX3-dependent retromer pathway mediates retrograde transport of the Wnt sorting receptor Wntless and is required for Wnt secretion. Nat Cell Biol 13: 914-923.

Henne WM, Buchkovich NJ, Zhao Y, Emr SD. 2012. The endosomal sorting complex ESCRT-II mediates the assembly and architecture of ESCRT-III helices. Cell 151: 356-371.

* Henne WM, Stenmark H, Emr SD. 2013. Molecular mechanisms of the membrane sculpting ESCRT pathway. Cold Spring Harb Perspect Biol 5: a016766.

Hoepfner S, Severin F, Cabezas A, Habermann B, Runge A, Gillooly D, Stenmark H, Zerial M. 2005. Modulation of receptor recycling and degradation by the endosomal kinesin KIF16B. Cell 121: 437-450.

Howes MT, Kirkham M, Riches J, Cortese K, Walser PJ, Simpson F, Hill MM, Jones A, Lundmark R, Lindsay MR, et al. 2010a. Clathrin-independent carriers form a high capacity endocytic sorting system at the leading edge of migrating cells. J Cell Biol 190: 675-691.

Howes MT, Mayor S, Parton RG. 2010b. Molecules, mechanisms, and cellular roles of clathrin-independent endocytosis. Curr Opin Cell Biol 22: 519-527.

Hullin-Matsuda F, Kawasaki K, Delton-Vandenbroucke I Xu Y, Nishijima M, Lagarde M, Schlame M, Kobayashi T. 2007. De novo biosynthesis of the late endosome lipid, bis(monoacylglycero)phosphate. J Lipid Res 48: 19972008.

Huotari J, Helenius A. 2011. Endosome maturation. EMBO J 30: 3481-3500.

Hurley JH, Boura E, Carlson LA, Rozycki B. 2010. Membrane budding. Cell 143: 875-887.

Hyman AA, Simons K. 2012. Cell biology. Beyond oil and water-Phase transitions in cells. Science 337: 10471049.

Ikonen E. 2008. Cellular cholesterol trafficking and compartmentalization. Nat Rev Mol Cell Biol 9: 125-138.

Ikonomov OC, Sbrissa D, Shisheva A. 2006. Localized PtdIns 3,5- $\mathrm{P}_{2}$ synthesis to regulate early endosome dy- 
namics and fusion. Am J Physiol Cell Physiol 291: C393C404.

Infante RE, Wang ML, Radhakrishnan A, Kwon HJ, Brown MS, Goldstein JL. 2008. NPC2 facilitates bidirectional transfer of cholesterol between NPC1 and lipid bilayers, a step in cholesterol egress from lysosomes. Proc Natl Acad Sci 105: 15287-15292.

Jeffries TR, Dove SK, Michell RH, Parker PJ. 2004. PtdInsspecific MPR pathway association of a novel WD40 repeat protein, WIPI49. Mol Biol Cell 15: 2652-2663.

* Johannes L, Wunder C, Bassereau P. 2013. Bending "on the rocks"-A cocktail of biophysical modules to build endocytic pathways. Cold Spring Harb Perspect Biol doi: 10.1101/cshperspect.a016741.

Johnstone RM. 2006. Exosomes biological significance: A concise review. Blood Cells Mol Dis 36: 315-321.

Joutti A. 1979. The stereoconfiguration of newly formed molecules of bis(monoacylglycero)phosphate in BHK cells. Biochim Biophys Acta 575: 10-15.

Kay JG, Koivusalo M, Ma X, Wohland T, Grinstein S. 2012. Phosphatidylserine dynamics in cellular membranes. Mol Biol Cell 23: 2198-2212.

* Kirchhausen T. 2013. Clathrin-mediated endocytosis I: Structure and design of CCVs. Cold Spring Harb Perspect Biol doi: 10.1101/cshperspect.a016725.

Kirkegaard T, Roth AG, Petersen NH, Mahalka AK, Olsen OD, Moilanen I, Zylicz A, Knudsen J, Sandhoff K, Arenz C, et al. 2010. Hsp70 stabilizes lysosomes and reverts Niemann-Pick disease-associated lysosomal pathology. Nature 463: 549-553.

Kobayashi T, Stang E, Fang KS, de Moerloose P, Parton RG, Gruenberg J. 1998. A lipid associated with the antiphospholipid syndrome regulates endosome structure and function. Nature 392: 193-197.

Kobayashi T, Beuchat MH, Lindsay M, Frias S, Palmiter RD, Sakuraba H, Parton RG, Gruenberg J. 1999. Late endosomal membranes rich in lysobisphosphatidic acid regulate cholesterol transport. Nat Cell Biol 1: 113-118.

Kobayashi T, Vischer UM, Rosnoblet C, Lebrand C, Lindsay M, Parton RG, Kruithof EK, Gruenberg J. 2000. The tetraspanin CD63/lamp3 cycles between endocytic and secretory compartments in human endothelial cells. Mol Biol Cell 11: 1829-1843.

Kobayashi T, Beuchat MH, Chevallier J, Makino A, Mayran N, Escola JM, Lebrand C, Cosson P, Kobayashi T, Gruenberg J. 2002. Separation and characterization of late endosomal membrane domains. J Biol Chem 277: 3215732164.

Kolter T, Sandhoff K. 2010. Lysosomal degradation of membrane lipids. FEBS Lett 584: 1700-1712.

Kwon HJ, Abi-Mosleh L, Wang ML, Deisenhofer J, Goldstein JL, Brown MS, Infante RE. 2009. Structure of N-terminal domain of NPC1 reveals distinct subdomains for binding and transfer of cholesterol. Cell 137: 1213-1224.

Laketa V, Zarbakhsh S, Morbier E, Subramanian D, Dinkel C, Brumbaugh J, Zimmermann P, Pepperkok R, Schultz C. 2009. Membrane-permeant phosphoinositide derivatives as modulators of growth factor signaling and neurite outgrowth. Chem Biol 16: 1190-1196.

Laulagnier K, Motta C, Hamdi S, Roy S, Fauvelle F, Pageaux JF, Kobayashi T, Salles JP, Perret B, Bonnerot C, et al. 2004.
Mast cell- and dendritic cell-derived exosomes display a specific lipid composition and an unusual membrane organization. Biochem J 380: 161-171.

Le Blanc I, Luyet PP, Pons V, Ferguson C, Emans N, Petiot A, Mayran N, Demaurex N, Faure J, Sadoul R, et al. 2005. Endosome-to-cytosol transport of viral nucleocapsids. Nat Cell Biol 7: 653-664.

Lemmon MA. 2008. Membrane recognition by phospholipid-binding domains. Nat Rev Mol Cell Biol 9: 99-111.

Leventis PA, Grinstein S. 2010. The distribution and function of phosphatidylserine in cellular membranes. Ann Rev Biophys 39: 407-427.

Lingwood D, Simons K. 2010. Lipid rafts as a membraneorganizing principle. Science 327: 46-50.

Liu TT, Gomez TS, Sackey BK, Billadeau DD, Burd CG. 2012. Rab GTPase regulation of retromer-mediated cargo export during endosome maturation. Mol Biol Cell 23: 2505-2515.

Lloyd TE, Atkinson R, Wu MN, Zhou Y, Pennetta G, Bellen HJ. 2002. Hrs regulates endosome membrane invagination and tyrosine kinase receptor signaling in Drosophila. Cell 108: 261-269.

Lloyd-Evans E, Morgan AJ, He X, Smith DA, Elliot-Smith E, Sillence DJ, Churchill GC, Schuchman EH, Galione A, Platt FM. 2008. Niemann-Pick disease type $\mathrm{C} 1$ is a sphingosine storage disease that causes deregulation of lysosomal calcium. Nat Med 14: 1247-1255.

Luquain C, Dolmazon R, Enderlin JM, Laugier C, Lagarde M, Pageaux JF. 2000. Bis(monoacylglycerol) phosphate in rat uterine stromal cells: Structural characterization and specific esterification of docosahexaenoic acid. Biochem J 351 (Pt 3): 795-804.

Luyet PP, Falguieres T, Pons V, Pattnaik AK, Gruenberg J. 2008. The ESCRT-I subunit TSG101 controls endosome-to-cytosol release of viral RNA. Traffic 9: 22792290.

Mari M, Bujny MV, Zeuschner D, Geerts WJ, Griffith J, Petersen CM, Cullen PJ, Klumperman J, Geuze HJ. 2008. SNX1 defines an early endosomal recycling exit for sortilin and mannose 6-phosphate receptors. Traffic 9: $380-393$.

Matsuo H, Chevallier J, Mayran N, Le Blanc I, Ferguson C, Faure J, Blanc NS, Matile S, Dubochet J, Sadoul R, et al. 2004. Role of LBPA and Alix in multivesicular liposome formation and endosome organization. Science 303: 531-534.

Maxfield FR, van Meer G. 2010. Cholesterol, the central lipid of mammalian cells. Curr Opin Cell Biol 22: 422-429.

Mayinger P. 2012. Phosphoinositides and vesicular membrane traffic. Biochim Biophys Acta 1821: 1104-1113.

Mayor S, Pagano RE. 2007. Pathways of clathrin-independent endocytosis. Nat Rev Mol Cell Biol 8: 603-612.

Mayran N, Parton RG, Gruenberg J. 2003. Annexin II regulates multivesicular endosome biogenesis in the degradation pathway of animal cells. EMBO J 22: $3242-$ 3253.

McBride HM, Rybin V, Murphy C, Giner A, Teasdale R, Zerial M. 1999. Oligomeric complexes link Rab5 effectors with NSF and drive membrane fusion via interactions between EEA1 and syntaxin 13. Cell 98: 377-386. 
Meikle PJ, Duplock S, Blacklock D, Whitfield PD, Macintosh G, Hopwood JJ, Fuller M. 2008. Effect of lysosomal storage on bis(monoacylglycero)phosphate. Biochem J 411: 71-78.

Mentel M, Laketa V, Subramanian D, Gillandt H, Schultz C. 2011. Photoactivatable and cell-membrane-permeable phosphatidylinositol 3,4,5-trisphosphate. Angewandte Chemie 50: 3811-3814.

* Merrifield C, Kaksonen M. 2013. Endocytic accessory factors and regulation of CME. Cold Spring Harb Perspect Biol doi: 10.1101/cshperspect.a016733.

Miller WL, Bose HS. 2011. Early steps in steroidogenesis: Intracellular cholesterol trafficking. J Lipid Res 52: 21112135.

Mobius W, van Donselaar E, Ohno-Iwashita Y, Shimada Y, Heijnen HF, Slot JW, Geuze HJ. 2003. Recycling compartments and the internal vesicles of multivesicular bodies harbor most of the cholesterol found in the endocytic pathway. Traffic 4: 222-231.

Mondal M, Mesmin B, Mukherjee S, Maxfield FR. 2009. Sterols are mainly in the cytoplasmic leaflet of the plasma membrane and the endocytic recycling compartment in CHO cells. Mol Biol Cell 20: 581-588.

Moravcevic K, Oxley CL, Lemmon MA. 2012. Conditional peripheral membrane proteins: Facing up to limited specificity. Structure 20: 15-27.

Morel E, Parton RG, Gruenberg J. 2009. Annexin A2-dependent polymerization of actin mediates endosome biogenesis. Dev Cell 16: 445-457.

Mukherjee S, Soe TT, Maxfield FR. 1999. Endocytic sorting of lipid analogues differing solely in the chemistry of their hydrophobic tails. J Cell Biol 144: 1271-1284.

Murk JL, Stoorvogel W, Kleijmeer MJ, Geuze HJ. 2002. The plasticity of multivesicular bodies and the regulation of antigen presentation. Semin Cell Dev Biol 13: 303-311.

Noda T, Matsunaga K, Taguchi-Atarashi N, Yoshimori T. 2010. Regulation of membrane biogenesis in autophagy via PI3P dynamics. Semin Cell Dev Biol 21: 671-676.

Odorizzi G, Babst M, Emr SD. 1998. Fablp PtdIns(3)P 5 kinase function essential for protein sorting in the multivesicular body. Cell 95: 847-858.

Ohgami N, Ko DC, Thomas M, Scott MP, Chang CC, Chang TY. 2004. Binding between the Niemann-Pick C1 protein and a photoactivatable cholesterol analog requires a functional sterol-sensing domain. Proc Natl Acad Sci 101: 12473-12478.

Oppelt A, Lobert VH, Haglund K, Mackey AM, Rameh LE, Liestol K, Schink KO, Pedersen NM, Wenzel EM, Haugsten EM, et al. 2013. Production of phosphatidylinositol 5-phosphate via PIKfyve and MTMR3 regulates cell migration. EMBO Rep 14: 57-64.

Pankiv S, Alemu EA, Brech A, Bruun JA, Lamark T, Overvatn A, Bjorkoy G, Johansen T. 2010. FYCO1 is a Rab7 effector that binds to LC3 and PI3P to mediate microtubule plus end-directed vesicle transport. J Cell Biol 188: 253-269.

Parisio G, Sperotto MM, Ferrarini A. 2012. Flip-flop of steroids in phospholipid bilayers: Effects of the chemical structure on transbilayer diffusion. J Am Chem Soc 134: $12198-12208$.

Pasqual G, Rojek JM, Masin M, Chatton JY, Kunz S. 2011. Old world arenaviruses enter the host cell via the multivesicu- lar body and depend on the endosomal sorting complex required for transport. PLoS Pathogens 7: e1002232.

Petiot A, Faure J, Stenmark H, Gruenberg J. 2003. PI3P signaling regulates receptor sorting but not transport in the endosomal pathway. J Cell Biol 162: 971-979.

Pons V, Luyet PP, Morel E, Abrami L, van der Goot FG, Parton RG, Gruenberg J. 2008. Hrs and SNX3 functions in sorting and membrane invagination within multivesicular bodies. PLoS Biol 6: e214.

Pons V, Ustunel C, Rolland C, Torti E, Parton RG, Gruenberg J. 2012. SNX12 role in endosome membrane transport. PloS ONE 7: e38949.

Poorthuis B, Hostetler KY. 1975. Biosynthesis of bis(monoacylglyceryl)phosphate and acylphosphatidylglycerol in rat liver mitochondrial. J Biol Chem 250: 3297-3302.

Prior IA, Muncke C, Parton RG, Hancock JF. 2003. Direct visualization of Ras proteins in spatially distinct cell surface microdomains. J Cell Biol 160: 165-170.

Raiborg C, Schink KO, Stenmark H. 2013. Class III phosphatidylinositol 3-kinase and its catalytic product PtdIns3P in regulation of endocytic membrane traffic. FEBS J 280: 2730-2742.

Ramel D, Lagarrigue F, Pons V, Mounier J, Dupuis-Coronas S, Chicanne G, Sansonetti PJ, Gaits-Iacovoni F, Tronchere H, Payrastre B. 2011. Shigella flexneri infection generates the lipid PI5P to alter endocytosis and prevent termination of EGFR signaling. Sci Signal 4: ra61.

Raposo G, Stoorvogel W. 2013. Extracellular vesicles: Exosomes, microvesicles, and friends. J Cell Biol 200: $373-$ 383.

Raposo G, Marks MS, Cutler DF. 2007. Lysosome-related organelles: Driving post-Golgi compartments into specialisation. Curr Opin Cell Biol 19: 394-401.

Riezman H, Johnsson K. 2011. Special issue: NCCR chemical biology. CHIMIA 65.

Rink J, Ghigo E, Kalaidzidis Y, Zerial M. 2005. Rab conversion as a mechanism of progression from early to late endosomes. Cell 122: 735-749.

Rojas R, van Vlijmen T, Mardones GA, Prabhu Y, Rojas AL, Mohammed S, Heck AJ, Raposo G, van der Sluijs P, Bonifacino JS. 2008. Regulation of retromer recruitment to endosomes by sequential action of Rab5 and Rab7. J Cell Biol 183: 513-526.

Romer W, Berland L, Chambon V, Gaus K, Windschiegl B, Tenza D, Aly MR, Fraisier V, Florent JC, Perrais D, et al. 2007. Shiga toxin induces tubular membrane invaginations for its uptake into cells. Nature 450: 670-675.

Roux A, Cuvelier D, Nassoy P, Prost J, Bassereau P, Goud B. 2005. Role of curvature and phase transition in lipid sorting and fission of membrane tubules. EMBO J 24: 1537-1545.

Rubinsztein DC, Shpilka T, Elazar Z. 2012. Mechanisms of autophagosome biogenesis. Curr Biol 22: R29-R34.

Rutherford AC, Traer C, Wassmer T, Pattni K, Bujny MV, Carlton JG, Stenmark H, Cullen PJ. 2006. The mammalian phosphatidylinositol 3-phosphate 5-kinase (PIKfyve) regulates endosome-to-TGN retrograde transport. J Cell Sci 119: 3944-3957.

Sbrissa D, Ikonomov OC, Deeb R, Shisheva A. 2002a. Phosphatidylinositol 5-phosphate biosynthesis is linked 
to PIKfyve and is involved in osmotic response pathway in mammalian cells. J Biol Chem 277: 47276-47284.

Sbrissa D, Ikonomov OC, Shisheva A. 2002b. Phosphatidylinositol 3-phosphate-interacting domains in PIKfyve. Binding specificity and role in PIKfyve. Endomembrane localization. J Biol Chem 277: 6073-6079.

Schmidt MH, Hoeller D, Yu J, Furnari FB, Cavenee WK, Dikic I, Bogler O. 2004. Alix/AIP1 antagonizes epidermal growth factor receptor downregulation by the Cbl-SETA/CIN85 complex. Mol Cell Biol 24: 89818993.

Schu PV, Takegawa K, Fry MJ, Stack JH, Waterfield MD, Emr SD. 1993. Phosphatidylinositol 3-kinase encoded by yeast VPS34 gene essential for protein sorting. Science 260: $88-91$.

Seaman MN. 2012. The retromer complex-Endosomal protein recycling and beyond. J Cell Sci 125: 4693-4702.

Seaman MN, Harbour ME, Tattersall D, Read E, Bright N. 2009. Membrane recruitment of the cargo-selective retromer subcomplex is catalysed by the small GTPase Rab7 and inhibited by the Rab-GAP TBC1D5. J Cell Sci 122: 2371-2382.

Sharma P, Varma R, Sarasij RC, Pastan I, Gousset K, Krishnamoorthy G, Rao M, Mayor S. 2004. Nanoscale organization of multiple GPI-anchored proteins in living cell membranes. Cell 116: 577-589.

Sharpe HJ, Stevens TJ, Munro S. 2010. A comprehensive comparison of transmembrane domains reveals organelle-specific properties. Cell 142: 158-169.

Shevchenko A, Simons K. 2010. Lipidomics: Coming to grips with lipid diversity. Nat Rev Mol Cell Biol 11: 593-598.

Shin HW, Hayashi M, Christoforidis S, Lacas-Gervais S, Hoepfner S, Wenk MR, Modregger J, Uttenweiler-Joseph S, Wilm M, Nystuen A, et al. 2005. An enzymatic cascade of Rab5 effectors regulates phosphoinositide turnover in the endocytic pathway. J Cell Biol 170: 607-618.

Simonsen A, Lippe R, Christoforidis S, Gaullier JM, Brech A, Callaghan J, Toh BH, Murphy C, Zerial M, Stenmark H. 1998. EEA1 links PI(3)K function to Rab5 regulation of endosome fusion. Nature 394: 494-498.

Simonsen A, Birkeland HC, Gillooly DJ, Mizushima N, Kuma A, Yoshimori T, Slagsvold T, Brech A, Stenmark H. 2004. Alfy, a novel FYVE-domain-containing protein associated with protein granules and autophagic membranes. J Cell Sci 117: 4239-4251.

Somerharju P, Renkonen O. 1980. Conversion of phosphatidylglycerol lipids to bis(monoacylglycero)phosphate in vivo. Biochim Biophys Acta 618: 407-419.

Sorre B, Callan-Jones A, Manneville JB, Nassoy P, Joanny JF, Prost J, Goud B, Bassereau P. 2009. Curvature-driven lipid sorting needs proximity to a demixing point and is aided by proteins. Proc Natl Acad Sci 106: 5622-5626.

Sousa LP, Lax I, Shen H, Ferguson SM, De Camilli P, Schlessinger J. 2012. Suppression of EGFR endocytosis by dynamin depletion reveals that EGFR signaling occurs primarily at the plasma membrane. Proc Natl Acad Sci 109: 4419-4424.

Steinman RM, Brodie SE, Cohn ZA. 1976. Membrane flow during pinocytosis. A stereologic analysis. J Cell Biol 68: $665-687$.
Steinman RM, Mellman IS, Muller WA, Cohn ZA. 1983. Endocytosis and the recycling of plasma membrane. $J$ Cell Biol 96: 1-27.

Stromhaug PE, Reggiori F, Guan J, Wang CW, Klionsky DJ. 2004. Atg21 is a phosphoinositide binding protein required for efficient lipidation and localization of Atg8 during uptake of aminopeptidase I by selective autophagy. Mol Biol Cell 15: 3553-3566.

Tan HH, Makino A, Sudesh K, Greimel P, Kobayashi T. 2012. Spectroscopic evidence for the unusual stereochemical configuration of an endosome-specific lipid. Angewandte Chemie 51: 533-535.

Thornburg T, Miller C, Thuren T, King L, Waite M. 1991. Glycerol reorientation during the conversion of phosphatidylglycerol to bis(monoacylglycerol)phosphate in macrophage-like RAW 264.7 cells. J Biol Chem 266: 68346840.

Tian A, Baumgart T. 2009. Sorting of lipids and proteins in membrane curvature gradients. Biophys J 96: 26762688.

* Tooze SA, Abada A, Elazar Z. 2013. Endocytosis and autophagy: Exploitation or cooperation? Cold Spring Harb Perspect Biol doi: 10.1101/cshperspect.a018358.

Touchberry CD, Bales IK, Stone JK, Rohrberg TJ, Parelkar NK, Nguyen T, Fuentes O, Liu X, Qu CK, Andresen JJ, et al. 2010. Phosphatidylinositol 3,5-bisphosphate (PI $(3,5)$ P2) potentiates cardiac contractility via activation of the ryanodine receptor. J Biol Chem 285: 4031240321.

Trajkovic K, Hsu C, Chiantia S, Rajendran L, Wenzel D, Wieland F, Schwille P, Brugger B, Simons M. 2008. Ceramide triggers budding of exosome vesicles into multivesicular endosomes. Science 319: 1244-1247.

Uchida Y, Hasegawa J, Chinnapen D, Inoue T, Okazaki S, Kato R, Wakatsuki S, Misaki R, Koike M, Uchiyama Y, et al. 2011. Intracellular phosphatidylserine is essential for retrograde membrane traffic through endosomes. Proc Natl Acad Sci 108: 15846-15851.

Vanier MT, Millat G. 2003. Niemann-Pick disease type C. Clin Genet 64: 269-281.

van Niel G, Charrin S, Simoes S, Romao M, Rochin L, Saftig P, Marks MS, Rubinstein E, Raposo G. 2011. The tetraspanin CD63 regulates ESCRT-independent and -dependent endosomal sorting during melanogenesis. Dev Cell 21: 708-721.

van Weering JR, Verkade P, Cullen PJ. 2012. SNX-BAR-mediated endosome tubulation is co-ordinated with endosome maturation. Traffic 13: 94-107.

Wemmer M, Azmi I, West M, Davies B, Katzmann D, Odorizzi G. 2011. Brol binding to Snf7 regulates ESCRT-III membrane scission activity in yeast. J Cell Biol 92: 295306.

Wenk MR. 2005. The emerging field of lipidomics. Nat Rev Drug Discov 4: 594-610.

Wilkening G, Linke T, Uhlhorn-Dierks G, Sandhoff K. 2000. Degradation of membrane-bound ganglioside $\mathrm{GM}_{1}$. Stimulation by bis(monoacylglycero)phosphate and the activator proteins SAP-B and $\mathrm{GM}_{2}$-AP. J Biol Chem 275: 35814-35819. 


\section{Bissig and J. Gruenberg}

Wollert T, Hurley JH. 2010. Molecular mechanism of multivesicular body biogenesis by ESCRT complexes. Nature 464: 864-869.

Wubbolts R, Leckie RS, Veenhuizen PT, Schwarzmann G, Mobius W, Hoernschemeyer J, Slot JW, Geuze HJ, Stoorvogel W. 2003. Proteomic and biochemical analyses of human B cell-derived exosomes. Potential implications for their function and multivesicular body formation. J Biol Chem 278: 10963-10972.

Wymann MP, Schultz C. 2012. The chemical biology of phosphoinositide 3-kinases. Chembiochem 13: 20222035.

Xu Y, Hortsman H, Seet L, Wong SH, Hong W. 2001. SNX3 regulates endosomal function through its PX-domain- mediated interaction with PtdIns(3)P. Nat Cell Biol 3: $658-666$.

Xu S, Benoff B, Liou HL, Lobel P, Stock AM. 2007. Structural basis of sterol binding by NPC2, a lysosomal protein deficient in Niemann-Pick type C2 disease. J Biol Chem 282: 23525-23531.

Zerial M, McBride H. 2001. Rab proteins as membrane organizers. Nat Rev Mol Cell Biol 2: 107-117.

Zolov SN, Bridges D, Zhang Y, Lee WW, Riehle E, Verma $\mathrm{R}$, Lenk GM, Converso-Baran $\mathrm{K}$, Weide $\mathrm{T}$, Albin RL, et al. 2012. In vivo, Pikfyve generates $\mathrm{PI}(3,5) \mathrm{P}_{2}$, which serves as both a signaling lipid and the major precursor for PI5P. Proc Natl Acad Sci 109: 1747217477. 


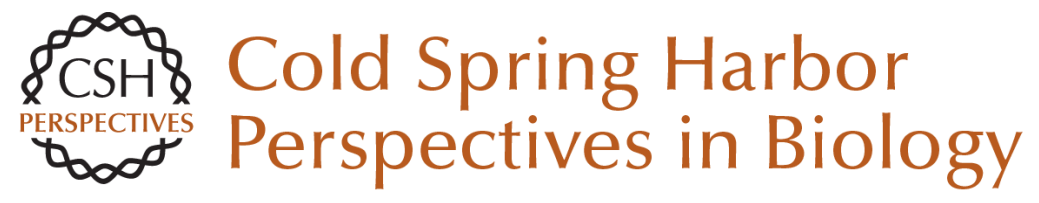

\section{Lipid Sorting and Multivesicular Endosome Biogenesis}

Christin Bissig and Jean Gruenberg

Cold Spring Harb Perspect Biol 2013; doi: 10.1101/cshperspect.a016816

Subject Collection Endocytosis

Endocytosis: Past, Present, and Future Sandra L. Schmid, Alexander Sorkin and Marino Zerial

Rab Proteins and the Compartmentalization of the Endosomal System Angela Wandinger-Ness and Marino Zerial

Cargo Sorting in the Endocytic Pathway: A Key Regulator of Cell Polarity and Tissue Dynamics Suzanne Eaton and Fernando Martin-Belmonte

Unconventional Functions for Clathrin, ESCRTs, and Other Endocytic Regulators in the Cytoskeleton, Cell Cycle, Nucleus, and Beyond: Links to Human Disease

Frances M. Brodsky, R. Thomas Sosa, Joel A. Ybe, et al.

Endocytosis of Viruses and Bacteria Pascale Cossart and Ari Helenius

Lysosomal Adaptation: How the Lysosome Responds to External Cues Carmine Settembre and Andrea Ballabio

Reciprocal Regulation of Endocytosis and Metabolism

Costin N. Antonescu, Timothy E. McGraw and Amira Klip

Endocytosis and Autophagy: Exploitation or Cooperation?

Sharon A. Tooze, Adi Abada and Zvulun Elazar
Imaging and Modeling the Dynamics of

Clathrin-Mediated Endocytosis

Marcel Mettlen and Gaudenz Danuser

Endocytic Accessory Factors and Regulation of

Clathrin-Mediated Endocytosis

Christien J. Merrifield and Marko Kaksonen

The Complex Ultrastructure of the Endolysosomal

System Judith Klumperman and Graça Raposo

The Biogenesis of Lysosomes and

Lysosome-Related Organelles

J. Paul Luzio, Yvonne Hackmann, Nele M.G.

Dieckmann, et al.

Endocytosis, Signaling, and Beyond Pier Paolo Di Fiore and Mark von Zastrow

Clathrin-Independent Pathways of Endocytosis Satyajit Mayor, Robert G. Parton and Julie G. Donaldson

The Role of Endocytosis during Morphogenetic Signaling Marcos Gonzalez-Gaitan and Frank Jülicher

Role of Endosomes and Lysosomes in Human Disease

Frederick R. Maxfield

For additional articles in this collection, see http://cshperspectives.cshlp.org/cgi/collection/

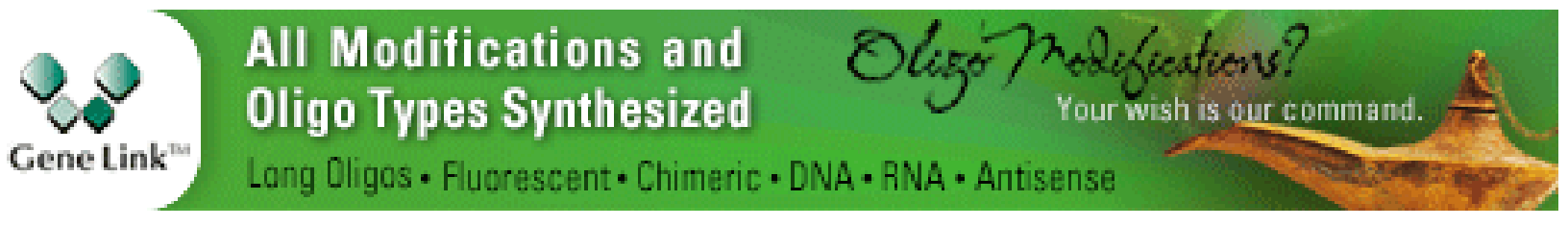


For additional articles in this collection, see http://cshperspectives.cshlp.org/cgi/collection/

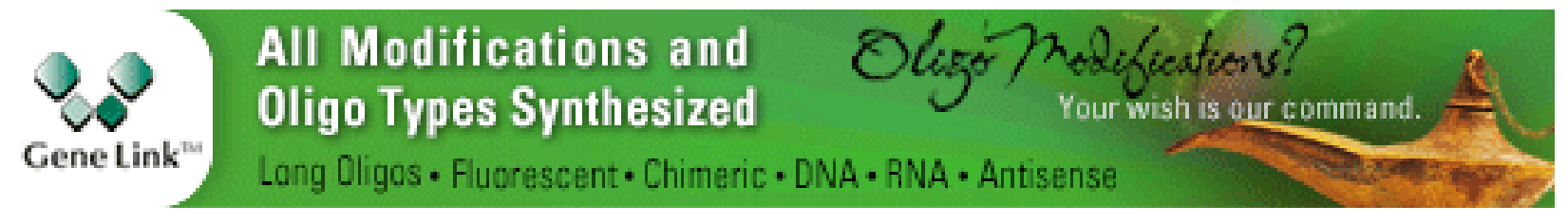

Copyright @ 2013 Cold Spring Harbor Laboratory Press; all rights reserved 